\title{
RESPONDING TO PRODUCT IN THE COMPOSING PROCESS
}

\author{
Sue Ling
}

The traditional method of responding to ESL students' written composition tends to stress linguistic accuracy, requiring the correction, usually by the teacher, of discrete grammatical items at the sentence level.

Studies by Hendrickson (1976) and Semke (1984) suggested that overt, indiscriminate and meticulous correction of student writing tended to have negative side effects on the quality of subsequent compositions and on student attitudes towards writing. A recent study by Zamel (1985) showed that ESL teachers ranked mechanical error as the most important criterion for responding to student writing, stating that compared to L1 writing teachers, they were even more concerned with language-specific errors and problems, responding to writing as if it were a final product.

In their study, Robb, Ross and Shortreed (1986) found that direct methods of feedback did not tend to produce results commensurate with the amount of effort required of the instructor to draw students' attention to surface errors, and that highly detailed feedback on sentence-level errors was not worth the instructors' time and effort.

Although it appears that there is no consensus on how teachers should best react to student writing, or at what stage in the composing process they should provide feedback on students' mechanical errors, Krashen (1984) recommended delaying corrective feedback on errors until the final stage of editing.

Krashen's suggestion reflects a growing understanding among researchers and teachers that writing involves producing a text that evolves over time. This has concomitantly resulted in a new and fresh approach for responding to student writing, a two-phase response, with the initial focus on content, delaying feedback on mechanical errors until "the work-in-progress" is fully shaped and becomes a finished product.

This staggered and discriminate feedback fosters a more realistic and positive attitude towards rewriting, which is thus separated into two distinct and sequential tasks, viz. revision for content/meaning and editing for form/mechanics. Not only is revision differentiated from editing, but it is also prioritized over editing, thus reflecting and reinforcing that language, be it spoken or written, is primarily a communicative tool; written composition is organized communication.

How is this response to writing more realistic? In responding first to the message/content, rather than to the form, teachers are showing cognizance of research which reveals that rewriting is an important part of the 
composing process. According to Murray (1978), writing means rewriting for most professional writers, and in support of his claim, he quotes 47 writers who state that they write and rewrite in order to discover/clarify what it is they have to say.

The process response to product provides a more positive attitude towards the task of rewriting in that teachers intervene (in students' writing) most opportunely and provide appropriate help without usurping the student's role as a writer, without distorting author intent and without overloading him/her cognitively with a dual injunction to revise for meaning and edit for mechanics at the same time.

In the traditional product-oriented approach, response to writing confounds revision with editing and students see the need for such an act as a signal that they have failed - this is regularly conveyed by the teacher's systematic blood-red ink.

Most beginning writers think that the first draft, the initial product, is equivalent to the finished product, and that mechanical changes of spelling, punctuation, capitalization and grammar, which are superficial or cosmetic changes, are all the shaping needed. Mature writers, on the other hand, know that the first draft is just the beginning, and that at this point in the writing cycle, they have completed only a part of the shaping process. We are reminded by Murray, "... the amateur thinks that the job is finished, but the professional knows that the job has just begun."

The ensuing paragraphs in this article will elaborate a classroom teacher's approach for responding to students' written composition within the process framework, at the King Edward Campus of Vancouver Community College.

The ESL division at K.E.C. offers English instruction in beginners, intermediate, advanced and college preparatory. Through initial placement tests and regular end-of-term tests, these classes are fairly homogeneous.

Based on a classroom practice called Talk-Write, in which one student talks and provides the focus of a "story" while his partner listens and tries to write it out for him, the following is the initial, unrevised and unedited product from a lower beginner, the lowest level in the ESL program:

I came to Canada about one year.

Draft 1, Comp. A

I am sewing masin opreter.

I have 6 brothers.

I like Canada because Canada is very butyfull country.

I go to school every night.

I like my teacher Tricia because she is nice teacher. 
As the reader may have noticed, this initial draft is very brief, typified by vagueness ("beautiful", "nice") and the words and phrases have special meanings to the writer not precise enough to the reader.

The traditional way of responding involves correcting the spelling and the grammar - corrective feedback exclusively on sentence-level errors. However, this does not result in an increase in understanding of the writer's intended meaning because the corrected or edited version still consists of six points or ideas, indicated by the six sentences.

To help the writer realize that his intended message has not been received and/or to find out what it is in his head that he wants to communicate to his reader, a simple question-answer procedure takes place as follows:

1. After the initial draft is written, the writer/originator of the story in Talk-Write gathers around a peer group (large or small) and invites feedback from this listening audience by saying, "I'm going to read my story aloud line by line. ASK ME QUESTIONS connected with the line because there may be things missing FOR YOU in order to understand it."

2. Tape the oral session to help the writer capture the essence of the interaction for rewriting.

In this particular session involving some lower beginners, after hearing the first line, (I came to Canada about one year), the listening audience asked the following questions:

Where did you come from?

How long have you been in Vancouver?

Did you come in winter?

Through these questions, the writer realized that important information was lacking in her composition; for example, when responding to the first question above, she exclaimed that she forgot to say she came from Viet-Nam.

The response to the second line (I am sewing maching operator) consisted of another series of questions:

What is sewing machine operator?

Did you make, in your country, machine dresses?

Do you make mens' clothes?

Here again, the writing/composition provided a focus for a high level of activity integrating listening, speaking and reading skills, which our ESL program emphasizes, and a lot of give-and-take.

In response to the third line (I have six brothers), the listening audience burst into laughter, and there were exclamations and expressions of 
amazement, questions and comments:

... six brothers!

Oh, only brothers? No sisters?

How many big, old brothers?

Where do you live?

Do you live with your brothers?

All family in one house?

How many people are in your family?

There was a delayed answer to the last question, and the writer burst out laughing because she took a long time to count the total number of people in her family, despite promptings from the audience, "Six people? eight? nine?"

Based on the taped feedback from the listening audience, the writer revised the initial draft as follows:

\title{
BETTY STORY
}

I'm from Viet-Nam. I have been Canada for one year.

I have parents, and six brothers and two sisters in law and three nephews, all my family live in Vancouver. We live in the two (The writer read it as town) house. My father is a tailor. He is 65 years old. So right now he doesn't go to work. My occupation is sewing machine operator. I like my job. My manager is Canadian, in the factory we talk English.

I like Vancouver. It is a beautiful city, It has many nice buildings, many park, there are many beautiful fowvers, many big mountains. The beaches have many big boats and ships ... E.T.C.

I don't like winter because it is snow and too cold. I hate snow, but I like summer time, although the wether too hot but air fresh, and I can go to swiming and go to the park play tennis, or can ride the bike ... E.T.C.

I go to night school. I lilke studying English. I like my teacher Tricia, she is a nice teacher. She taught English too easy understood. She is happy and very kind a teacher. She is Canadian. She is 27 years old. She is friendly and easy to talk to. She is pretty.

\author{
Betty $\mathrm{T}$. \\ L. Beginners \\ Draft 2, Comp. A.
}


The following is a summary observation when comparing the initial draft, the revised draft and the transcript of the tape:

1. Some of the original sentences have been re-phrased and modified, represented by broken lines;

2. The revised draft is much longer. The numbers in brackets on the right margin represent the six original sentences;

3. Prompted by the listening audience, the writer has provided a title for the revised draft;

4. There is more specific information on the writer's family;

5. The writer has refined her points, for example, that she likes Vancouver (not really Canada);

6. The writer has given more details and examples to support her points; for example, she has elaborated why she likes Vancouver, summer, and her teacher, and why she dislikes winter.

7. The writer has not included all the points or issues raised at the oral session; thus, she has exercised a writer's ultimate right to choose what to include or exclude from her own writing.

When giving a student a mark for writing/composition, our evaluation criteria takes semantics, syntax and mechanics into consideration; a student gets a mark each for the initial product, and for the revised and/or edited product chosen for submission. The final mark for that composition is the average of the two scores.

Here is another revision procedure that has been used at K.E.C.:

1. After the initial draft is written, the writer, in a group, invites feedback from a listening audience consisting of his/her peers), by saying, "I'm going to read my composition line by line. Tell me when the picture from that line is not clear to you because I'd like to visualize/picture things in your mind, and share my thoughts and my experience."

2. Tape the oral session to help the writer revise.

Based on Talk-Write, the following is an initial draft from a lower advanced student in our program:

\section{LIKE VANCOUVER}

Vancouver is a beautiful, clean, hardly polluted, peaceful and excellent city to live in. Vancouver is a perfectly size city and there is a very high standard of living.

Although it may rain an awlful lot in Vancouver, there are many different activities and sports such as lying down 
on the sandy beaches, skiing on the beautiful mountains or shopping in one of the many malls. Vancouver is a very nice place with many malls. Vancouver is a very nice place with many nice neighborhoods and friendly people.

Coming soon Expo 86 will be bringing thousands of tourist to Vancouver, and it will be an exciting event for our city.

There is a very good educational system for Vancouver students because of many good private and public schools. Moreover, Vancouver is an outstanding city and I would not prefer to live anywhere else.

\author{
Magdalena \\ L. Advanced \\ Draft 1, Comp. A
}

When reporting the proceedings involving the writer of the above composition when he read aloud to his listening audience, it was interesting to note that, since the opening sentence has five separate points or ideas, the listening group interrupted the reading to seek examples from the writer on what was beautiful, what was meant by "clean, hardly polluted", "peaceful" and "excellent."

Moreover, since the composition is expository in nature, at the end of each paragraph, the writer and the listening audience discussed the following:

1. What is the paragraph mostly about? (What is the main idea?)

2. What are the best examples or details or facts to support that idea/point?

Based on the interaction with the listening audience which was taped, the writer revised as follows:

\title{
WHY I LIKE VANCOUVER
}

There are many reasons why I like Vancouver. Firstly, it is a beautiful city. It is located in a beautiful setting, like near the coast mountains and the ocean. The parks in Vancouver is not only clean, but also beautiful. The Stanely Park, which is the largest park in Vancouver, have a zoo and the Vancouver Public Aquarium. Stanley Park is also known for its flower gardens. Queen Elizabeth Park is also beautiful for there is an arboretum, a place where the rare trees and shrubs are grown. 
Next, Vancouver is not polluted, refering to the water and air. For example, the water is not dirty. There is no germs or chemicals that can cause disease. The air is always fresh because the Automobiles exhaust or smoke from the factory doesn't create pollution.

Vancouver is also peaceful city. The street life is quite and calm. It is not so dangerous to walk in the street during the night comparing to other place like California.

Again, I like Vancouver because the city is not an overcrowded. The number of people living in the city are not too many comparing to New York which is one of the crowded city.

Vancouver has a mild climate that makes the year around attractive for many activities such as going to the beaches, skiing on the beautiful mountains, fishing, golfing and tennis.

Wherever I go around the city, there are many friendly people. They smile and say hello to me and sometimes talk a bit as if we were a best friend.

Another reason why I like Vancouver is because of the Expo 86 is coming soon. It will be bringing thousands of tourist to Vancouver from all over the world. For example people from America, Europe and Asia are coming to Vancouver to see the Expo 86. As a result, it will be an exciting event for our city.

Lastly, I have noticed that Vancouver has a very good educational system. The public school operates the Vancouver School of Art and the Vancouver Vocational Institute. There is an upgrading that helps the students who have problems to that specific program. Forign students whose English is a second language has to passed an English Assessment Test when applying for admission to the universities and colleges.

For all these reasons I prefer to live in Vancouver more than anywhere else.

\author{
Magdalena \\ Lower Advanced \\ Draft 2, Comp. A
}

NOTE: The points contained in the initial draft are represented by continuous lines and the broken lines represent re-phrasing of original ideas.

The data provided so far seems to suggest that beginning or inexpe- 
rienced ESL writers do not realize that the message sent out (via written composition) is not precise and, therefore, has not been received. Immediate feedback from peers serving as a listening audience can provide valuable help to the writer to revise for content/message. Since the peer group is not looking at the written message, they respond readily and effectively to the ideas. If they read/see the initial written product, they tend to respond to the spelling and other mechanical aspects of writing, and the ideas get neglected or pushed aside unwittingly.

Once the meaning is complete, that is to say, the message is clear, it seems appropriate and necessary to respond to the mechanical or socalled cosmetic aspects of writing - this is the final editing stage of response to product within the framework of teaching writing as a process.

Experienced teachers have undoubtedly found that providing the correct form/structure for students' faulty sentences is a time-consuming ordeal which is frustrating to teachers, since identical types of errors appear repeatedly on compositions over a period of time. Furthermore, overt correction is also disconcerting to students, although many claim that they want it!

Moreover, as mentioned earlier, research has shown us that teachergenerated correction is not effective.

Therefore, in our editing stage of responding to product in teaching writing within the process framework, we have proceeded as follows:

1. At the beginning of the term, based on revised drafts written by students within the class, where the meaning/content has been fully developed, the teacher and the class, working in groups, single out high-priority errors, categorize these errors, and collectively devise an abbreviated and practical code system for these errors.

2. This abbreviated code system is then compiled as a checklist of grammatical errors. Since the checklist arises from the class, it is meaningful and clear to all users in subsequent marking, be they peer groups, individuals or teachers.

3. Implement peer group marking - in pairs or in small groups, using the home-made checklist, with the teacher as a consultant in controversial/undecided cases.

4. Hold regular, scheduled teacher-student conferencing. Insist that each student's revised draft be accompanied by an error category chart listing the high-priority errors, error frequency and causes (carelessness or ignorance of rule). See the attached error category chart by Lower Advanced student, Magdalena.

5. Provide remedial or reinforcement work to overcome ignorance 
of the usage of the language.

6. Put the responsibility of learning where it rightly belongs - with the student; broaden his awareness of resource material/person, e.g. consulting a dictionary for the spelling or meaning of a word, as we ourselves do when we write.

7. Use a grammatical progress chart to help the learner see/monitor progress - see example attached.

In conclusion, when responding to the product in teaching writing as a process, we should understand the stage in the writing process the product has reached and respond appropriately. For example, does the product need more shaping and clarifying so that the student-writer can communicate the meaning fully? Is it at the final stage where help in editing is needed? Appropriate and supportive feedback and intervention involving peer groups and the teacher-consultant can lead to better products and also a strong sense to the student-writer that his role as writer has not been usurped, but that a positive audience can help him to achieve his goals and purposes in communicating through writing.

Student: Magdalena

L. Advanced

Error Categories for Draft 2, Composition A

(Why I like Vancouver)

\begin{tabular}{|c|c|c|c|}
\hline & \multicolumn{3}{|c|}{ Cause of Error } \\
\hline & $\begin{array}{l}\text { No. of } \\
\text { times }\end{array}$ & Careless & $\begin{array}{l}\text { Didn't } \\
\text { know rule }\end{array}$ \\
\hline 1. $\mathrm{S}-\mathrm{V}$ agreement & |||| & & \|\| \\
\hline $\begin{array}{l}\text { 2. Incorr. V form (doesn't } \\
\text { created; to passed) }\end{array}$ & $\|$ & & $\|$ \\
\hline $\begin{array}{l}\text { 3. Incorr. } \mathrm{N} \text { form } \\
\text { (one of the crowded city; } \\
\text { we were a best friend; } \\
\text { thousands of tourist) }\end{array}$ & $\mid \|$ & $\|$ & \\
\hline $\begin{array}{l}\text { 4. Incorr. use of ing/ed ending } \\
\text { (... comparing to California; } \\
\text {... comparing to New York) }\end{array}$ & $\|$ & $\|$ & \\
\hline $\begin{array}{l}\text { 5. Spelling } \\
\text { (refering/referring } \\
\text { quite/quiet } \\
\text { forign/foreign) }\end{array}$ & || $\mid$ & $\|$ & cont'd. \\
\hline
\end{tabular}


Error Categories for Draft 2, Composition A, cont'd.

\begin{tabular}{llll}
\hline & \multicolumn{3}{c}{ Cause of Error } \\
\hline & $\begin{array}{l}\text { No. of } \\
\text { times }\end{array}$ & Careless & $\begin{array}{l}\text { Didn't } \\
\text { know rule }\end{array}$ \\
\hline $\begin{array}{l}\text { 6. Article } \\
\text { a. omission } \\
\text { b. unnecessary use } \\
\text { c. mixing up } a \text { and the }\end{array}$ & & & \\
\hline
\end{tabular}

Note: Each draft bears a number, and each composition topic/assignment bears a letter, A, B, C, etc.

Student: Magdalena

L. Advanced

\section{Grammatical Progress Chart}

\begin{tabular}{llll}
\hline Error Categories & \multicolumn{3}{c}{ Composition } \\
& A & B & C \\
\hline 1. S-V agreement & 4 & 2 \\
2. Incorr. V form & 2 & 0 \\
3. Incorr. N form & 3 & 0 \\
4. Incorr. use of ing/ed ending & 2 & 0 \\
5. Spelling & 3 & 1 \\
6. Article & & \\
a. omission & 1 & 0 \\
b. unnecessary use & 5 & 6 \\
c. mixing up $a$, the & 1 & 1 \\
7. Comma splice & 0 & 1 \\
8. Tense shift & 0 & 5 \\
\hline
\end{tabular}

(It is interesting to report that, through peer interaction and given more time, Magdalena found a more appropriate title for composition A. In her final draft (draft 3), revised and edited with peer help, she deleted the second last paragraph from draft 2, which, among other things, contains incorrect information on the Vancouver School Board. Finally, it is also noteworthy that when the classroom teacher looked at her final draft, which she submitted for a mark, a lot of the careless mistakes had vanished.) 


\section{REFERENCES}

Cooper, C. and L. Odell. (1977). Evaluating writing. Urbana, Illinois: National Council of Teachers of English.

Crowhurst, M. (1979). The writing workshop: an experiment in peer response to writing. Language Arts 56, 7-10.

Emig, J. (1977). Writing as a mode of learning. College Composition and Communication 28(2), 122-127.

Griffin, C. (1982). Theory of responding to student writing: the state of the art. College Composition and Communication 33, 296-301.

Hartfiel, V. Faye, J. Hughey, D. Wormuth \& H. Jacobs. (1985). Learning ESL composition. Rowley, Mass: Newbury House.

Hendrickson, J. (1976). The effects of error correction treatments upon adequate and accurate communication in the written compositions of adult learners of English as a second language. Ph.D dissertation, Ohio State University.

Henrickson, J. (1978). Error correction in foreign language teaching: recent theory, research, and practice. Modern Language Journal 62(8), 387-398.

Hughey, Wormuth, Hartfiel \& Jacobs. (1983). Teaching ESL composition: Principles and techniques. Rowley, Mass: Newbury House.

\section{THE AUTHOR}

Sue Ling has an M. Ed. degree from the University of British Columbia. She has given a number of workshops to professional groups on teaching writing as a process, elaborating strategies for prewriting, writing and rewriting. She has been teaching ESL at the King Edward Campus of Vancouver Community College since 1972. 